\title{
Implementasi Data Mining Untuk Menentukan Persediaan Stok Obat Di Enok Menggunakan Metode K-Means Clustering
}

\author{
Ferlanda $^{1}$, Septi Andryana ${ }^{2}$, Eri Mardiani ${ }^{3}$ \\ ${ }^{1,2,3}$ Universitas Nasional, Informatika, Fakultas Teknologi Komunikasi dan Informatika \\ Jl. Sawo Manila, Pejaten Ps. Minggu Jakarta 12520 \\ e-mail: ${ }^{1}$ ahmadferlanda10@gmail.com, ${ }^{2}$ septi.andryana@civitas.unas.ac.id, \\ 3 erimardiani1@gmail.com
}

\begin{abstract}
Abstrak
Pengolahan data mining telah berkembang sangat pesat, beradaptasi dengan segala bentuk analisis data. Pada dasarnya, data mining dapat menganalisis data untuk menggunakan teknik perangkat lunak untuk menemukan pola dalam kumpulan data tersembunyi. Manajemen persediaan yang tinggi dan tidak ekonomis karena beberapa produk mungkin memiliki ruang dan kelebihan. Hal ini tentu sangat merugikan pelaku usaha seperti tempat kesehatan Apotek Enok. Metode K-Means sudah menjadi salah satu teknik data mining yang digunakan untuk merancang strategi persediaan atau buku pesanan yang efektif menggunakan data transaksi penjualan bisnis. Tujuan penelitian dari penelitian ini adalah untuk menerapkan algoritma $K$ Means, dan data transaksi obat dari Apotek Enok di berikan sebagai contoh tipikal. Hasil analisis untuk penelitian ini menggunakan 20 buah data. Pengumpulan data obat yang di lakukan dengan algortma K-Means diulang sebanyak tiga kali, kemudian didapatkan hasil kelompok yaitu kelompok 1 berisi 6 obat kerja lambat dan kelompok 2 terdapat 14 obat kerja cepat. Pencarian cluster ini menggunakan fitur web untuk menemukan produk lambat dan obat cepat.
\end{abstract}

Kata kunci-Algoritma, Data Mining, K-Means, Stok, Website

\begin{abstract}
Data mining processing has developed very rapidly, adapting to all forms of data analysis. Basically, data mining can analyze data to use software techniques to find patterns in hidden data sets. High and uneconomical inventory management because some products may have space and excess. This is certainly very detrimental to business actors such as the health center of the Enok Pharmacy. The K-Means method has become one of the data mining techniques used to design an effective inventory strategy or order book using business sales transaction data. The research objective of this study is to apply the K-Means algorithm, and drug transaction data from the Enok Pharmacy is given as a typical example. The results of the analysis for this study used 20 pieces of data. Drug data collection was carried out using the $K$ Means algorithm and was repeated three times, then the group results were group 1 containing 6 slow-acting drugs and group 2 containing 14 fast-acting drugs. This cluster search uses web features to find slow products and fast drugs.
\end{abstract}

Keywords-Algorithm, Data Mining, K-Means, Stock, Website 


\section{PENDAHULUAN}

$\mathrm{K}$ esehatan adalah hak asasi manusia dan berkontribusi pada keberhasilan pembangunan Indonesia. Oleh karena itu, pembangunan kesehatan yang komprehensif dan berkelanjutan diperlukan untuk meningkatkan kesadaran, kesiapan, dan kapasitas seluruh masyarakat untuk menerapkan perilaku hidup sehat guna mencapai derajat kesehatan masyarakat yang tinggi.

Saat ini Apotek Enok belum dapat melaksanakan kegiatan pelayanan kefarmasian sesuai rencana karena berbagai kendala seperti kemampuan apoteker, keterbatasan pengetahuan manajemen apoteker karena fungsi apoteker dan kebijakan mengenai kelembagaan manajemen apoteker. Pengetahuan direktur farmasi dan pemangku kepentingan masih terbatas.

Salah satu metode data mining yang tersedia dalam analisis di atas adalah clustering. Dalam pengelompokan ini, item data dikelompokkan menjadi beberapa subkelompok dan setiap kelompok memiliki kesamaan. Algoritma yang relevan dan banyak digunakan adalah Algoritma K-Means. Algoritma ini didasarkan pada ide sederhana. Pertama, ditentukan jumlah cluster yang terbentuk yaitu dengan memilih semua objek atau elemen pertama dalam cluster untuk bertindak sebagai titik pusat (titik kontrol) cluster. Selain itu, informasi yang dihasilkan menggunakan data mining dapat digunakan dalam klaim Apotek Enok untuk meningkatkan pelayanan publik.

Dalam penelitian "Mengukur Kinerja Metode K-Means Dengan Pembanding Dalam Meningkatkan Kualitas Citra X-Ray" menggunakan hasil gambar rontgen untuk melihat penyakit penyakit tulang, dan rontgen pasien terkadang menghasilkan gambar yang buruk untuk mencegah optimalisasi proses diagnostic dokter.[1], Selanjutnya, "Penerapan Data mining Pada Ekspor Buah-Buahan Menurut Negara Tujuan Menggunakan K-Means Clustering Method" penelitian lain menerapkan algoritma K-Means untuk mengelompokkan buah-buahan yang di ekspor berdasarkan negara tujuan.[2], Penelitian "Implementasi algoritma k-means cluster untuk rekomendasi pekerjaan berdasarkan pengelompokkan data penduduk" Algoritma Kmeans dalam penelitian ini menggunakan empat cluster.[3], Pada penelitian "Penerapan KMeans Cluster Pada Daerah Potensi Pertanian Karet Produktif di Sumatera Utara", berikut, algoritma K-Means digunakan untuk mengurutkan daerah potensial produksi karet di Sumatera Utara.[4], Berikut kajian "Penerapan Metode K-Means Cluster Analysis Pada Sistem Pendukung Keputusan Pemilihan Konsentrasi Untuk Mahasiswa International Class Stmik Amikom Yogyakarta".[5], Penelitian "Aplikasi Pengelompokan Pelanggan Pada Ums Store Menggunakan Algoritma Kmeans, Program Studi Informatika, Fakultas Komunikasi dan Informatika",[6], Penelitiannya pada penerapan algoritma K-Means clastering analysis untuk epidemic manusia.[7], Penelitian pengelola perusahaan harus memperhatikan aspek dari jumlah jenis barang maupun artikel dari barang tersebut. Metode yang digunakan pada penelitian ini adalah menggunakan teknik Clustering K-Means yang merupakan salah satu metode yang populer dan banyak digunakan.[8].

\section{METODE PENELITIAN}

Metode pencarian ini menerapkan Algoritma K-Means Clustering, metode pengelompokan beberapa dataset atau objek.

\subsection{Clustering}

Clustering adalah metode pengelompokan bagian atau kumpulan data atau objek sehingga objek yang sejenis menjadi cluster atau kelompok. [11] 


\section{2 Algoritma K-Means}

K-Means merupakan teknik clustering yang diperoleh dari sebuah dataset dengan cara menghitung jarak dari setiap titik ke pusat cluster secara iterative [12]. Algoritma K-Means memiliki beberapa aturan yaitu:

1. Total cluster yang dibutuhkan

2. Jenis atribut adalah numeric

Proses untuk clustering menggunkan algoritma k-means adalah sebagai berikut :

1. Tentukan nilai $\mathrm{k}$ dalam total cluster yang ingin dibentuk.

2. Pilih nilai centroid cluster (centroid) berawal dari $\mathrm{k}$.

3. Hitung jarak setiap data input dan setiap centroid menggunakan rumus jarak Euclidean untuk menemukan jarak terdekat antara setiap titik data dan centroid.

4. Mengklasifikasikan/mengelompokan setiap item data berlandaskan jarak (jarak minimum) ke centroid.

5. Perbarui mediannya. Nilai pusat baru.

6. Mengulangi langkah ke 3 sampai 5 anggota setiap cluster tetap tidak berubah.

\section{3 Website}

Web merupakan bagian dari World Wide Web dan merupakan fitur yang iminta oleh pengguna komputer yang terhubung kedalam internet. Website memberikan informasi kepada pengguna komputer yang terhubung ke internet [13].

\section{4 My $S Q L$}

Structured Query Language merupakan bahasa query tersturuktu. SQL terstruktur untuk digunakan dan memiliki aturan yang ditetapkan oleh asosiasi yang dikenal sebagai ANSI.

SQL merupakan bahasa yang dipergunakan untuk mengakses suatu data dalam database relasional [14].

\section{5 Metode Pengumpulan Data}

Sumber data yang dipergunakan dalam penelitian ini merupakan data transaksional di Apotek Enok mengenai konsumsi obat. Data tersebut diolah untuk menciptakan pengetahuan yang dapat digunakan sebagai strategi untuk mengembangkan strategi pengelolaan persediaan obat. Data awal yang diperoleh dari Apotek Enok disimpan sebagai data semua konsumsi obat selama 5 bulan terakhir.

Langkah-langkah prosedur menggunakan K menyiratkan metode pengelompokan berikut:

1. Tentukan nilai $\mathrm{k}$ untuk jumlah cluster yang ingin dibentuk.

2. Pilih pusat cluster awal (centroid) nilai $\mathrm{k}$.

3. Hitung jarak dari setiap data input ke setiap centroid menggunakan rumus jarak Euclidean dan temukan jarak terdekat dari setiap data ke centroid.

4. Mengklasifikasikan/mengelompokkan setiap item data berdasarkan kedekatannya (jarak minimum) ke centroid.

5. Perbarui nilai pusat. Centroid baru diambil dari mean cluster tersebut menggunakan rumus.

Mengulangi langkah 3 sampai 5 anggota setiap cluster tetap tidak berubah. Dalam penelitian ini, mempergunakan K-Means Clustering berbasis web untuk pengujian. Hal ini didasarkan pada penghitungan algoritma K-Means Clustering dalam aplikasi yang dirancang untuk membuat keputusan yang digunakan untuk mengidentifikasi penggunaan obat.

\section{6 Metode Pengembangan Waterfall}

Pengembangan dan perancangan dalam merancang perangkat lunak menggunakan metode waterfall [4]. Metode ini mencakup beberapa langkah. 
1. Analisis Kebutuhan Langkah ini dilakukan dalam menganalisis kebutuhan sistem yang berkaitan dengan kebutuhan pengguna sistem.

2. Desain Sistem

Ditahap ini bertujuan berfokus pada desain untuk membuat perangkat lunak.

3. Implementasi Kode Melakukan langkah-langkah menulis kode pemrograman berdasarkan hasil sebelum mengeksekusi kode.

4. Pengujian

Tahapan ini merupakan tahapan untuk mendeteksi dan memperbaiki kesalahan pada sistem pengujian.

5. Pemeliharaan

Lakukan pemeliharaan perangkat lunak secara teratur pada tahap ini.

\section{HASIL DAN PEMBAHASAN}

\section{1 Implementasi algoritma K-Means}

Ketika data siap untuk diproses, algoritma K-Means memproses data pada gambar 1 dibawah ini:

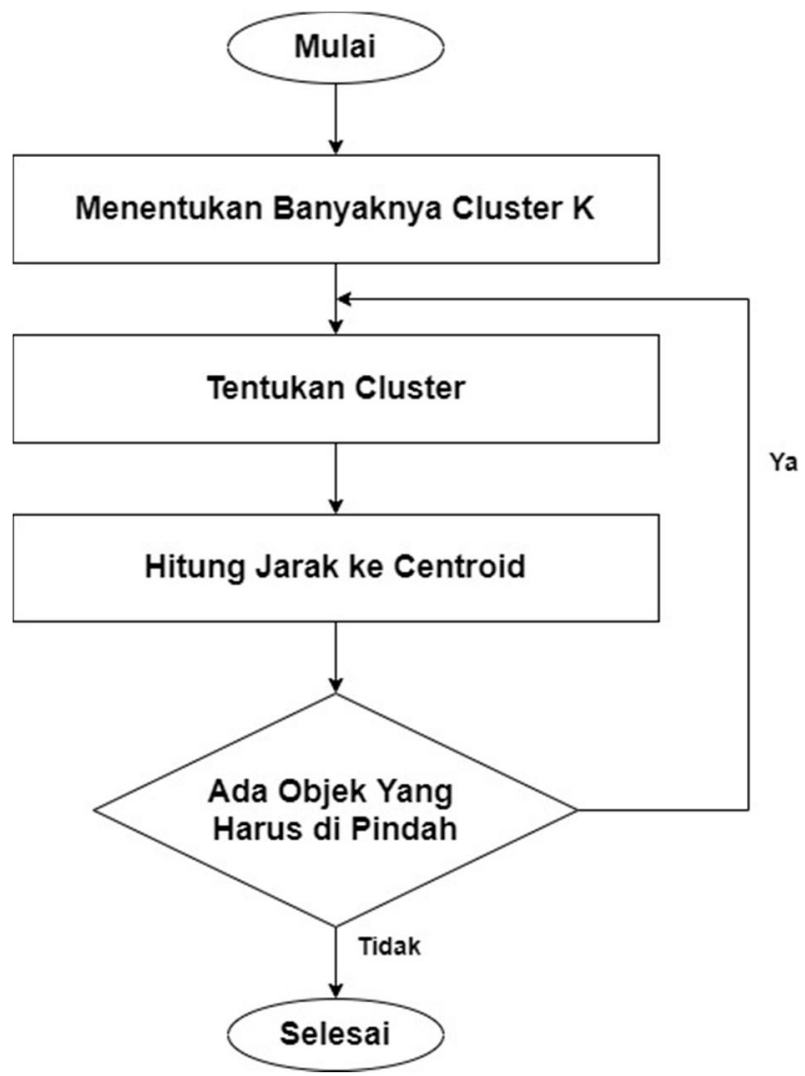

Gambar 1. Tahapan Algoritma K-Means 
Basis pengetahuan merupakan sesuatu yang penting bagi analisa data mining. Data obat ditampilkan dalam bentuk tabel 1dibawah ini:

\begin{tabular}{cllccccc}
\hline & & \multicolumn{2}{l}{ Tabel 1. Data Pemakaian Obat } & & & \\
\hline Data ke & \multicolumn{1}{c}{ Nama Obat } & Satuan & Bulan 1 & Bulan 2 & Bulan 3 & Bulan 4 & Bulan 5 \\
\hline 1 & AmoksilinSyr Ker & Botol & 8 & 5 & 5 & 7 & 6 \\
2 & Paracetamol & Tablet & 5 & 4 & 9 & 4 & 5 \\
3 & Amoksillin Kap & Pcs & 5 & 7 & 8 & 4 & 8 \\
& 500mg & & & & & & \\
4 & Dumexilin & Salep & 7 & 4 & 6 & 2 & 9 \\
5 & Panadol & Box & 7 & 3 & 5 & 5 & 5 \\
6 & Oskadon & Tablet & 5 & 7 & 3 & 9 & 7 \\
7 & Acyclovir & Tablet & 6 & 7 & 4 & 8 & 5 \\
8 & Alodan & Tablet & 7 & 8 & 4 & 7 & 3 \\
9 & Abbocath & Pcs & 5 & 7 & 3 & 6 & 5 \\
10 & Alkohol 70 \% & Botol & 5 & 6 & 4 & 7 & 6 \\
11 & Betadine & Pcs & 5 & 9 & 3 & 5 & 7 \\
12 & Aspilet & Tablet & 3 & 2 & 5 & 3 & 2 \\
13 & Bufacaryl & Vial & 4 & 7 & 9 & 5 & 8 \\
14 & Bufantasyd & Box & 3 & 5 & 4 & 6 & 2 \\
15 & Bevalex Cream & Pcs & 7 & 8 & 5 & 6 & 4 \\
16 & Borogmol supp & Botol & 4 & 6 & 3 & 5 & 3 \\
17 & Bioplacenton Salf & Tablet & 7 & 6 & 8 & 4 & 5 \\
18 & Captensin & Salep & 4 & 2 & 5 & 3 & 4 \\
19 & Carbamazepin & Pcs & 5 & 6 & 4 & 7 & 6 \\
20 & Cefadroxyl Tab & Tablet & 5 & 9 & 8 & 5 & 7 \\
& & & & & & & \\
\hline
\end{tabular}

\subsection{Contoh Perhitungan Manual Metode K-Means Clustering}

Berdasarkan gambar 3.1 langkah-langkah dalam algoritma K-Means dapat dijabarkan sebagai berikut

1. Mulai

2. Menentukan jumlah cluster $\mathrm{k}$

Setelah menentukan jumlah cluster pada penelitian ini, bagi cluster menjadi dua cluster yaitu obat kerja lambat dan obat kerja cepat (C1 dan C2). Serta menyesuaikan.

3. Studi penentuan Cluster (Fokus) menurut Joanna Ardhiyanti M.N dan Yupie Kusumawati, penentuan focus awal K-Means adalah acak. Oleh karena itu, dalam penelitian ini, pusat awal secara acak mengumpulkan dua data, Kelompok $\mathrm{C} 1$ dan $\mathrm{C} 2$, dan mengambil masingmasing atribut. Paracetamol 5, 4, 9, 4, 5 dan Panadol 7, 3, 5, 5, 5. Menghitung jarak dari data ke pusat langkah selanjutnya adalah menghitung jarak data ke titik pusat menggunakan jarak Euclidean atau jarak terdekat untuk mendapatkan hasil data ke cluster $\mathrm{C} 1$ atau cluster $\mathrm{C} 2$.

Iterasi pertama jarak data ke pusat $\mathrm{C} 1$.

Data ke 1: $\{8,5,5,7,6\}$

$$
\begin{aligned}
d \text { Euclidean }(M 1) & =\sqrt{(8-5)^{2}+(5-4)^{2}+(5-9)^{2}+(7-4)^{2}+(6-5)^{2}} \\
& =6
\end{aligned}
$$

Ferlanda, et., al [Implementasi Data Mining Untuk Menentukan Persediaan Stok Obat Di Enok Menggunakan 


$$
\begin{aligned}
d \text { Euclidean }(M 2) & =\sqrt{(8-7)^{2}+(5-3)^{2}+(5-5)^{2}+(7-5)^{2}+(6-5)^{2}} \\
& =3.16
\end{aligned}
$$

Data ke $2:\{5,4,9,4,5\}$

$$
\begin{aligned}
d \text { Euclidean }(M 1) & =\sqrt{(5-5)^{2}+(4-4)^{2}+(9-9)^{2}+(4-4)^{2}+(5-5)^{2}} \\
& =0 \\
d \text { Euclidean }(M 2)= & \sqrt{(5-7)^{2}+(4-3)^{2}+(9-5)^{2}+(4-5)^{2}+(5-5)^{2}} \\
= & 4.69
\end{aligned}
$$

(Sampai data selanjutnya)

4. Apabila terdapat objek atau data yang berpindah maka ulangi perulangan hingga iterasi

\begin{tabular}{|c|c|c|c|c|c|c|c|c|c|c|}
\hline \multicolumn{11}{|c|}{ Tabel 3. Perhitungan Iterasi Pertama } \\
\hline $\begin{array}{l}\text { Data } \\
\text { ke }\end{array}$ & Nama Obat & Satuan & $\begin{array}{c}\text { Bulan } \\
1 \\
\end{array}$ & $\begin{array}{c}\text { Bulan } \\
2 \\
\end{array}$ & $\begin{array}{c}\text { Bulan } \\
3 \\
\end{array}$ & $\begin{array}{c}\text { Bulan } \\
4 \\
\end{array}$ & $\begin{array}{c}\text { Bulan } \\
5 \\
\end{array}$ & $\mathrm{C} 1$ & $\mathrm{C} 2$ & Kategori \\
\hline 1 & $\begin{array}{l}\text { AmoksilinSyr } \\
\text { Ker }\end{array}$ & Botol & 8 & 5 & 5 & 7 & 6 & 6 & 3.16 & $\mathrm{C} 2$ \\
\hline 2 & Paracetamol & Tablet & 5 & 4 & 9 & 4 & 5 & 0 & 4.69 & $\mathrm{C} 1$ \\
\hline 3 & $\begin{array}{l}\text { Amoksillin Kap } \\
\text { 500mg }\end{array}$ & Pcs & 5 & 7 & 8 & 4 & 8 & 4.36 & 6.24 & $\mathrm{C} 1$ \\
\hline 4 & Dumexilin & Salep & 7 & 4 & 6 & 2 & 9 & 5.74 & 5.2 & $\mathrm{C} 2$ \\
\hline 5 & Panadol & Box & 7 & 3 & 5 & 5 & 5 & 4.69 & 0 & $\mathrm{C} 2$ \\
\hline 6 & Oskadon & Tablet & 5 & 7 & 3 & 9 & 7 & 8.6 & 6.63 & $\mathrm{C} 2$ \\
\hline 7 & Acyclovir & Tablet & 6 & 7 & 4 & 8 & 5 & 7.14 & 5.2 & $\mathrm{C} 2$ \\
\hline 8 & Alodan & Tablet & 7 & 8 & 4 & 7 & 3 & 7.62 & 5.83 & $\mathrm{C} 2$ \\
\hline 9 & Abbocath & Pcs & 5 & 7 & 3 & 6 & 5 & 7 & 5 & $\mathrm{C} 2$ \\
\hline 10 & Alkohol $70 \%$ & Botol & 5 & 6 & 4 & 7 & 6 & 6.24 & 4.36 & $\mathrm{C} 2$ \\
\hline 11 & Betadine & Pcs & 5 & 9 & 3 & 5 & 7 & 8.12 & 6.93 & $\mathrm{C} 2$ \\
\hline 12 & Aspilet & Tablet & 3 & 2 & 5 & 3 & 2 & 5.83 & 5.48 & $\mathrm{C} 2$ \\
\hline 13 & Bufacaryl & Vial & 4 & 7 & 9 & 5 & 8 & 4.47 & 7.07 & $\mathrm{C} 1$ \\
\hline 14 & Bufantasyd & Box & 3 & 5 & 4 & 6 & 2 & 6.56 & 5.57 & $\mathrm{C} 2$ \\
\hline 15 & Bevalex Cream & Pcs & 7 & 8 & 5 & 6 & 4 & 6.4 & 5.2 & $\mathrm{C} 2$ \\
\hline 16 & Borogmol supp & Botol & 4 & 6 & 3 & 5 & 3 & 6.78 & 5.1 & $\mathrm{C} 2$ \\
\hline 17 & $\begin{array}{l}\text { Bioplacenton } \\
\text { Salf }\end{array}$ & Tablet & 7 & 6 & 8 & 4 & 5 & 3 & 4.36 & $\mathrm{C} 1$ \\
\hline 18 & Captensin & Salep & 4 & 2 & 5 & 3 & 4 & 4.8 & 3.87 & $\mathrm{C} 2$ \\
\hline 19 & Carbamazepin & Pcs & 5 & 6 & 4 & 7 & 6 & 6.24 & 4.36 & $\mathrm{C} 2$ \\
\hline 20 & Cefadroxyl Tab & Tablet & 5 & 9 & 8 & 5 & 7 & 5.57 & 7.28 & $\mathrm{C} 1$ \\
\hline
\end{tabular}
sampai tidak ada lagi yang berpindah.

5. Selesai.

Setelah dihitung sebagai iterasi pertama, dengan titik pusat diatas maka dihasilkan seperti tabel 2 dibawah ini:

\begin{tabular}{rrrrr}
\hline \multicolumn{5}{c}{ Tabel 2. Titik Pusat 1 } \\
\hline V1 & V2 & V3 & V4 & V5 \\
\hline 5 & 4 & 9 & 4 & 5 \\
7 & 3 & 5 & 5 & 5
\end{tabular}

Pada perhitungan iterasi pertama, dihasilkan dari 20 data terdapat 5 anggota dengan kategori $\mathrm{C} 1$ dan 15 anggota dengan kategori $\mathrm{C} 2$. Kemudian dilanjutkan dengan menghitung 
iterasi kedua, pada hitungan iterasi kedua digunakan titik pusat cluster yang baru. Untuk mengupdate nilai titik pusat cluster, caranya dengan mencari nilai rata pada masing-masing Cluster. Maka dihasilkan seperti pada tabel 4 dan 5 dibawah ini:

\begin{tabular}{ccccc}
\hline \multicolumn{5}{c}{ Tabel 4. Titik Pusat 2 } \\
\hline V1 & V2 & V3 & V4 & V5 \\
\hline 5.2 & 6.6 & 8.4 & 4.4 & 6.6 \\
5.4 & 5.67 & 4.2 & 5.73 & 4.93
\end{tabular}

\begin{tabular}{|c|c|c|c|c|c|c|c|c|c|c|}
\hline \multicolumn{11}{|c|}{ Tabel 5. Perhitungan Iterasi Kedua } \\
\hline $\begin{array}{l}\text { Data } \\
\text { ke }\end{array}$ & Nama Obat & Satuan & $\begin{array}{c}\text { Bulan } \\
1\end{array}$ & $\begin{array}{l}\text { Bulan } \\
2\end{array}$ & $\begin{array}{c}\text { Bulan } \\
3\end{array}$ & $\begin{array}{c}\text { Bulan } \\
4\end{array}$ & $\begin{array}{l}\text { Bulan } \\
5\end{array}$ & $\mathrm{C} 1$ & $\mathrm{C} 2$ & Kategori \\
\hline 1 & $\begin{array}{l}\text { AmoksilinSyr } \\
\text { Ker }\end{array}$ & Botol & 8 & 5 & 5 & 7 & 6 & 5.39 & 3.26 & $\mathrm{C} 2$ \\
\hline 2 & Paracetamol & Tablet & 5 & 4 & 9 & 4 & 5 & 3.14 & 5.38 & $\mathrm{C} 1$ \\
\hline 3 & $\begin{array}{l}\text { Amoksillin Kap } \\
\text { 500mg }\end{array}$ & Pcs & 5 & 7 & 8 & 4 & 8 & 1.57 & 5.37 & $\mathrm{C} 1$ \\
\hline 4 & Dumexilin & Salep & 7 & 4 & 6 & 2 & 9 & 5.22 & 6.25 & $\mathrm{C} 1$ \\
\hline 5 & Panadol & Box & 7 & 3 & 5 & 5 & 5 & 5.54 & 3.3 & $\mathrm{C} 2$ \\
\hline 6 & Oskadon & Tablet & 5 & 7 & 3 & 9 & 7 & 7.12 & 4.28 & $\mathrm{C} 2$ \\
\hline 7 & Acyclovir & Tablet & 6 & 7 & 4 & 8 & 5 & 5.97 & 2.71 & $\mathrm{C} 2$ \\
\hline 8 & Alodan & Tablet & 7 & 8 & 4 & 7 & 3 & 6.65 & 3.66 & $\mathrm{C} 2$ \\
\hline 9 & Abbocath & Pcs & 5 & 7 & 3 & 6 & 5 & 5.87 & 1.86 & $\mathrm{C} 2$ \\
\hline 10 & Alkohol $70 \%$ & Botol & 5 & 6 & 4 & 7 & 6 & 5.18 & 1.75 & $\mathrm{C} 2$ \\
\hline 11 & Betadine & Pcs & 5 & 9 & 3 & 5 & 7 & 5.96 & 4.18 & $\mathrm{C} 2$ \\
\hline 12 & Aspilet & Tablet & 3 & 2 & 5 & 3 & 2 & 7.79 & 5.99 & $\mathrm{C} 2$ \\
\hline 13 & Bufacaryl & Vial & 4 & 7 & 9 & 5 & 8 & 2.07 & 6.06 & $\mathrm{C} 1$ \\
\hline 14 & Bufantasyd & Box & 3 & 5 & 4 & 6 & 2 & 7.1 & 3.86 & $\mathrm{C} 2$ \\
\hline 15 & Bevalex Cream & Pcs & 7 & 8 & 5 & 6 & 4 & 5.11 & 3.09 & $\mathrm{C} 2$ \\
\hline 16 & Borogmol supp & Botol & 4 & 6 & 3 & 5 & 3 & 6.65 & 2.79 & $\mathrm{C} 2$ \\
\hline 17 & $\begin{array}{l}\text { Bioplacenton } \\
\text { Salf }\end{array}$ & Tablet & 7 & 6 & 8 & 4 & 5 & 2.55 & 4.48 & $\mathrm{C} 1$ \\
\hline 18 & Captensin & Salep & 4 & 2 & 5 & 3 & 4 & 6.55 & 4.94 & $\mathrm{C} 2$ \\
\hline 19 & Carbamazepin & Pcs & 5 & 6 & 4 & 7 & 6 & 5.18 & 1.75 & $\mathrm{C} 2$ \\
\hline 20 & Cefadroxyl Tab & Tablet & 5 & 9 & 8 & 5 & 7 & 2.55 & 5.52 & $\mathrm{C} 1$ \\
\hline
\end{tabular}

Sementara itu, keputusan kelompok ditunjukkan pada tabel 6 dibawah ini:

\begin{tabular}{ccc}
\hline \multicolumn{3}{c}{ Tabel 6. Hasil Iterasi Pertama dan Kedua } \\
\hline Data ke 1 & Iterasi 1 & Iterasi 2 \\
\hline 1 & $\mathrm{C} 2$ & $\mathrm{C} 2$ \\
2 & $\mathrm{C} 1$ & $\mathrm{C} 1$ \\
3 & $\mathrm{C} 1$ & $\mathrm{C} 1$ \\
4 & $\mathrm{C} 2$ & $\mathrm{C} 1$ \\
5 & $\mathrm{C} 2$ & $\mathrm{C} 2$ \\
6 & $\mathrm{C} 2$ & $\mathrm{C} 2$
\end{tabular}

Ferlanda, et., al [Implementasi Data Mining Untuk Menentukan Persediaan Stok Obat Di Enok Menggunakan Metode K-Means Clustering] 
Jatisi

ISSN 2407-4322

Vol. 8, No. 3, September 2021, Hal. 1294-1306

E- ISSN 2503-2933 1301

$\begin{array}{lll}7 & \mathrm{C} 2 & \mathrm{C} 2 \\ 8 & \mathrm{C} 2 & \mathrm{C} 2 \\ 9 & \mathrm{C} 2 & \mathrm{C} 2 \\ 10 & \mathrm{C} 2 & \mathrm{C} 2 \\ 11 & \mathrm{C} 2 & \mathrm{C} 2 \\ 12 & \mathrm{C} 2 & \mathrm{C} 2 \\ 13 & \mathrm{C} 1 & \mathrm{C} 1 \\ 14 & \mathrm{C} 2 & \mathrm{C} 2 \\ 15 & \mathrm{C} 2 & \mathrm{C} 2 \\ 16 & \mathrm{C} 2 & \mathrm{C} 2 \\ 17 & \mathrm{C} 1 & \mathrm{C} 1 \\ 18 & \mathrm{C} 2 & \mathrm{C} 2 \\ 19 & \mathrm{C} 2 & \mathrm{C} 2 \\ 20 & \mathrm{C} 1 & \mathrm{C} 1\end{array}$

Sebelum memutuskan cluster baru, harus mendefinisikan ulang pada iterasi kedua karena ada data yang telah dipindahkan kelompok oleh cluster centroid untuk diperbarui dan pada iterasi pertama ditemukan bahwa cluster tersebut belum konvergen, kapasitor. Ulangi dengan centroid cluster yang perlu diperbarui.

\begin{tabular}{clccc}
\hline \multicolumn{5}{l}{ Tabel 7. Titik Pusat 3 } \\
\hline V1 & V2 & V3 & V4 & V5 \\
\hline 5.5 & 6.17 & 8 & 4 & 7 \\
5.29 & 5.79 & 4.07 & 6 & 4.64
\end{tabular}

Tabel 8. Perhitungan Iterasi Ketiga

\begin{tabular}{|c|c|c|c|c|c|c|c|c|c|c|}
\hline $\begin{array}{l}\text { Data } \\
\text { ke }\end{array}$ & Nama Obat & Satuan & $\begin{array}{c}\text { Bulan } \\
1\end{array}$ & $\begin{array}{c}\text { Bulan } \\
2\end{array}$ & $\begin{array}{c}\text { Bulan } \\
3\end{array}$ & $\begin{array}{c}\text { Bulan } \\
4\end{array}$ & $\begin{array}{c}\text { Bulan } \\
5\end{array}$ & $\mathrm{C} 1$ & $\mathrm{C} 2$ & Kategori \\
\hline 1 & $\begin{array}{l}\text { AmoksilinSyr } \\
\text { Ker }\end{array}$ & Botol & 8 & 5 & 5 & 7 & 6 & 5.16 & 3.42 & $\mathrm{C} 2$ \\
\hline 2 & Paracetamol & Tablet & 5 & 4 & 9 & 4 & 5 & 3.16 & 5.63 & $\mathrm{C} 1$ \\
\hline 3 & $\begin{array}{l}\text { Amoksillin Kap } \\
\text { 500mg }\end{array}$ & Pcs & 5 & 7 & 8 & 4 & 8 & 1.39 & 5.68 & $\mathrm{C} 1$ \\
\hline 4 & Dumexilin & Salep & 7 & 4 & 6 & 2 & 9 & 4.35 & 6.7 & $\mathrm{C} 1$ \\
\hline 5 & Panadol & Box & 7 & 3 & 5 & 5 & 5 & 5.13 & 3.56 & $\mathrm{C} 2$ \\
\hline 6 & Oskadon & Tablet & 5 & 7 & 3 & 9 & 7 & 7.14 & 4.15 & $\mathrm{C} 2$ \\
\hline 7 & Acyclovir & Tablet & 6 & 7 & 4 & 8 & 5 & 6.08 & 2.47 & $\mathrm{C} 2$ \\
\hline 8 & Alodan & Tablet & 7 & 8 & 4 & 7 & 3 & 6.83 & 3.39 & $\mathrm{C} 2$ \\
\hline 9 & Abbocath & Pcs & 5 & 7 & 3 & 6 & 5 & 5.83 & 1.68 & $\mathrm{C} 2$ \\
\hline 10 & Alkohol $70 \%$ & Botol & 5 & 6 & 4 & 7 & 6 & 5.13 & 1.73 & $\mathrm{C} 2$ \\
\hline 11 & Betadine & Pcs & 5 & 9 & 3 & 5 & 7 & 5.85 & 4.25 & $\mathrm{C} 2$ \\
\hline 12 & Aspilet & Tablet & 3 & 2 & 5 & 3 & 2 & 7.66 & 6.04 & $\mathrm{C} 2$ \\
\hline 13 & Bufacaryl & Vial & 4 & 7 & 9 & 5 & 8 & 2.44 & 6.3 & $\mathrm{C} 1$ \\
\hline 14 & Bufantasyd & Box & 3 & 5 & 4 & 6 & 2 & 7.25 & 3.58 & $\mathrm{C} 2$ \\
\hline 15 & Bevalex Cream & Pcs & 7 & 8 & 5 & 6 & 4 & 5.25 & 3.01 & $\mathrm{C} 2$ \\
\hline 16 & Borogmol supp & Botol & 4 & 6 & 3 & 5 & 3 & 6.65 & 2.56 & $\mathrm{C} 2$ \\
\hline 17 & $\begin{array}{l}\text { Bioplacenton } \\
\text { Salf }\end{array}$ & Tablet & 7 & 6 & 8 & 4 & 5 & 2.51 & 4.75 & $\mathrm{C} 1$ \\
\hline 18 & Captensin & Salep & 4 & 2 & 5 & 3 & 4 & 6.22 & 5.13 & $\mathrm{C} 2$ \\
\hline
\end{tabular}

Ferlanda, et., al [Implementasi Data Mining Untuk Menentukan Persediaan Stok Obat Di Enok Menggunakan Metode K-Means Clustering] 


$\begin{array}{lllllllllll}19 & \text { Carbamazepin } & \text { Pcs } & 5 & 6 & 4 & 7 & 6 & 5.13 & 1.73 & \text { C2 }\end{array}$

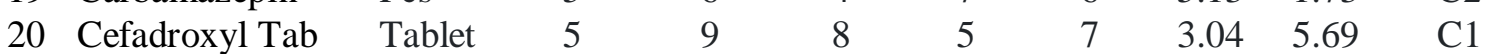

Keputusan kelompok, disisi lain, dapat dilihat pada tabel 9 dibawah ini:

\begin{tabular}{cccc}
\hline \multicolumn{4}{c}{ Tabel 9. Hasil Iterasi Pertama dan Kedua } \\
\hline Data ke 1 & Iterasi 1 & Iterasi 2 & Iterasi 3 \\
\hline 1 & $\mathrm{C} 2$ & $\mathrm{C} 2$ & $\mathrm{C} 2$ \\
2 & $\mathrm{C} 1$ & $\mathrm{C} 1$ & $\mathrm{C} 1$ \\
3 & $\mathrm{C} 1$ & $\mathrm{C} 1$ & $\mathrm{C} 1$ \\
4 & $\mathrm{C} 2$ & $\mathrm{C} 1$ & $\mathrm{C} 1$ \\
5 & $\mathrm{C} 2$ & $\mathrm{C} 2$ & $\mathrm{C} 2$ \\
6 & $\mathrm{C} 2$ & $\mathrm{C} 2$ & $\mathrm{C} 2$ \\
7 & $\mathrm{C} 2$ & $\mathrm{C} 2$ & $\mathrm{C} 2$ \\
8 & $\mathrm{C} 2$ & $\mathrm{C} 2$ & $\mathrm{C} 2$ \\
9 & $\mathrm{C} 2$ & $\mathrm{C} 2$ & $\mathrm{C} 2$ \\
10 & $\mathrm{C} 2$ & $\mathrm{C} 2$ & $\mathrm{C} 2$ \\
11 & $\mathrm{C} 2$ & $\mathrm{C} 2$ & $\mathrm{C} 2$ \\
12 & $\mathrm{C} 2$ & $\mathrm{C} 2$ & $\mathrm{C} 2$ \\
13 & $\mathrm{C} 1$ & $\mathrm{C} 1$ & $\mathrm{C} 1$ \\
14 & $\mathrm{C} 2$ & $\mathrm{C} 2$ & $\mathrm{C} 2$ \\
15 & $\mathrm{C} 2$ & $\mathrm{C} 2$ & $\mathrm{C} 2$ \\
16 & $\mathrm{C} 2$ & $\mathrm{C} 2$ & $\mathrm{C} 2$ \\
17 & $\mathrm{C} 1$ & $\mathrm{C} 1$ & $\mathrm{C} 1$ \\
18 & $\mathrm{C} 2$ & $\mathrm{C} 2$ & $\mathrm{C} 2$ \\
19 & $\mathrm{C} 2$ & $\mathrm{C} 2$ & $\mathrm{C} 2$ \\
20 & $\mathrm{C} 1$ & $\mathrm{C} 1$ & $\mathrm{C} 1$
\end{tabular}

Pada iterasi 2, setiap kelompok data dianggap optimal jika dinyatakan konvergen daripada berubah.

Hasil analisis ditunjukkan pada tabel 9 diatas sebagai berikut:

Karena hasil iterasi ke-3 dan ke-2 sama, maka tidak perlu dilanjutkan ke iterasi ke-4 dan berhenti di iterasi ke-3. Kelompok tersebut kemudian dinyatakan kovergen atau sudah dianggap optimal.

Pengumpulan data obat menggunakan algoritma K-Means menghasilkan hasil komposit setelah iterasi ke-3. Artinya, kelompok 1 memiliki 6 anggota yang mengonsumsi obat lambat dan kelompok 2 mengonsumsi obat cepat ada 14 anggota.

\section{3 Halaman Aplikasi}

a. Halaman utama Aplikasi 


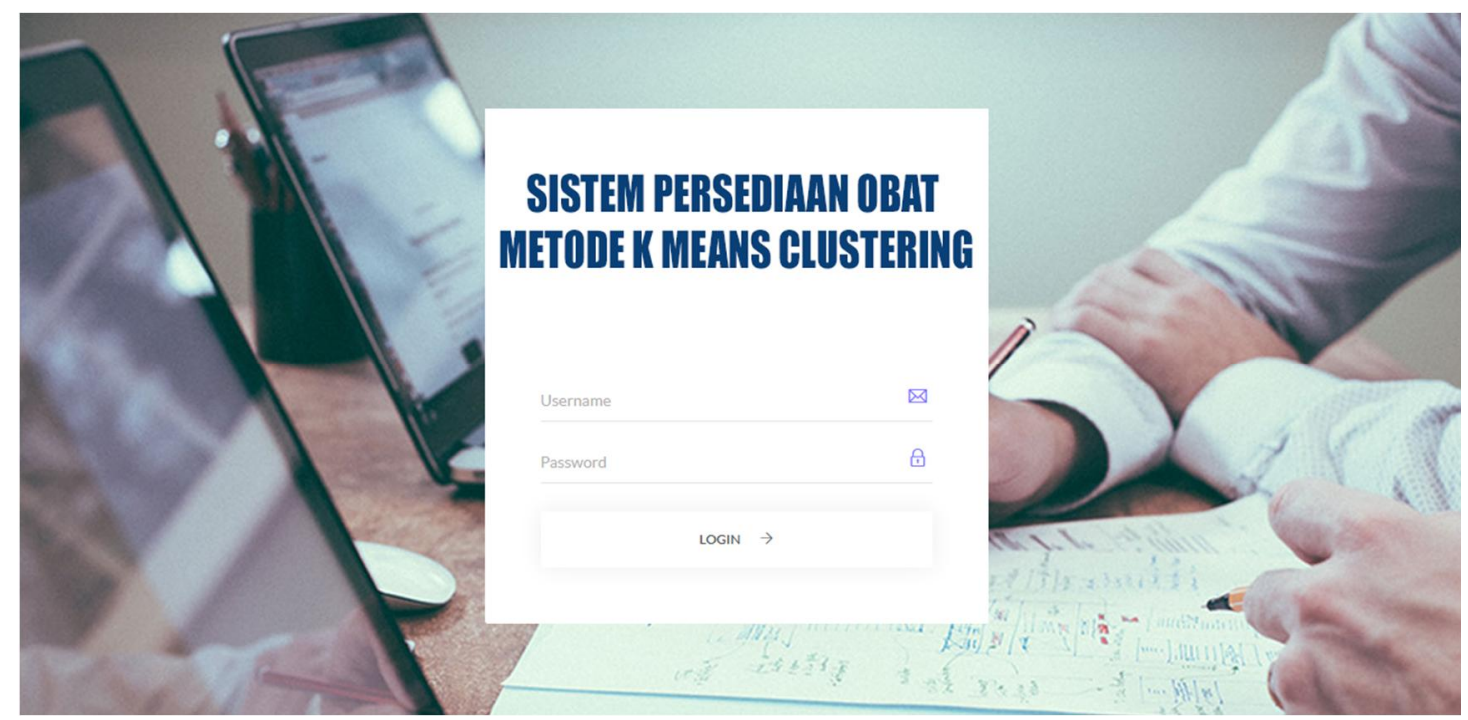

Gambar 2. Halaman Utama Aplikasi

Gambar 2 merupakan tampilan pertama ketika pengguna membuka aplikasi Implementasi Data Mining Untuk Menentukan Persediaan Stok Obat Di Apotek Enok Menggunakan Metode K-Means Clustering. Halaman ini berisikan form login dengan mengisi username dan password. b. Halaman Dasbord

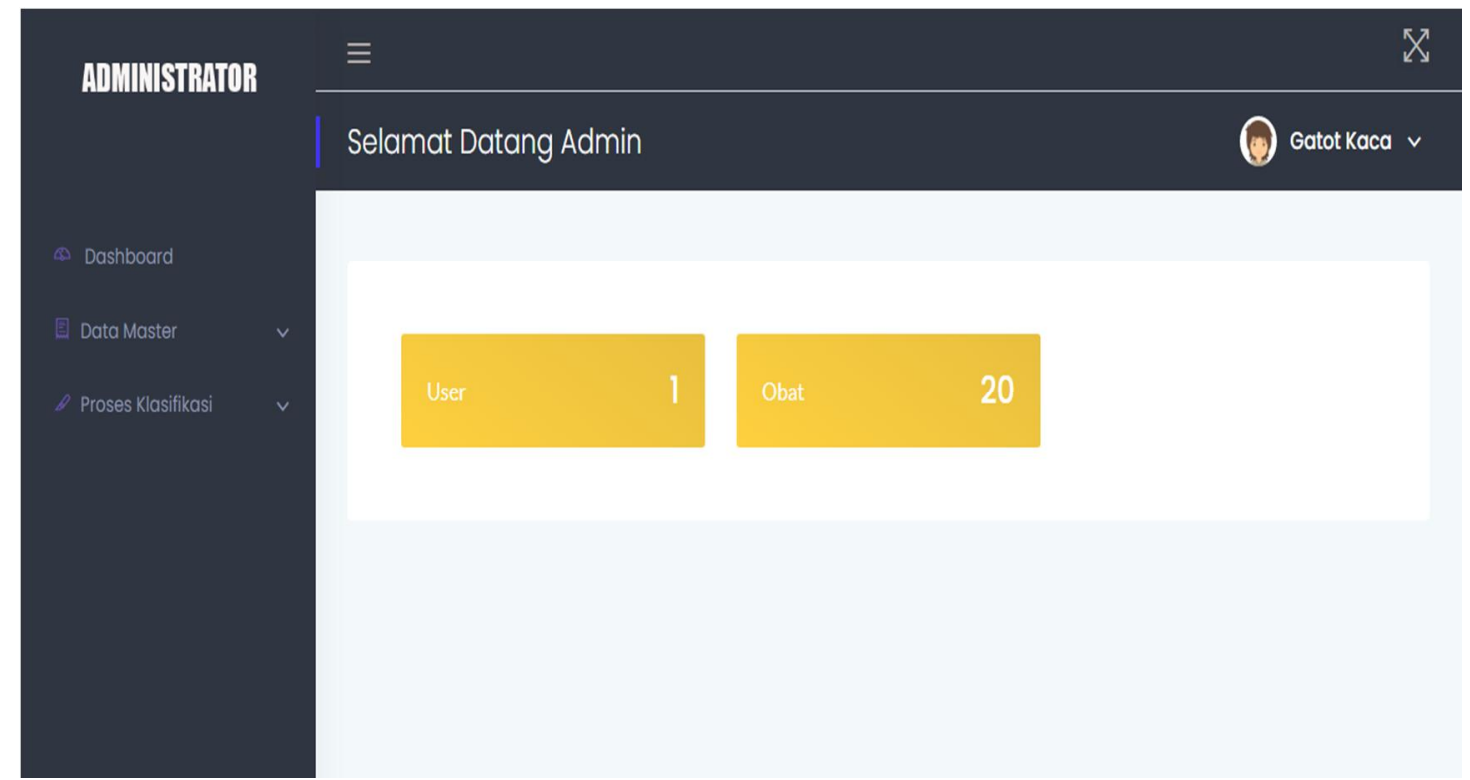

Gambar 3. Halaman Dasbord

Gambar 3 merupakan tampilan dashboard. Pada halaman ini terdapat menu data master yaitu user dan data obat. Kemudian menu proses klasifikasi.

c. Halaman Data Obat 


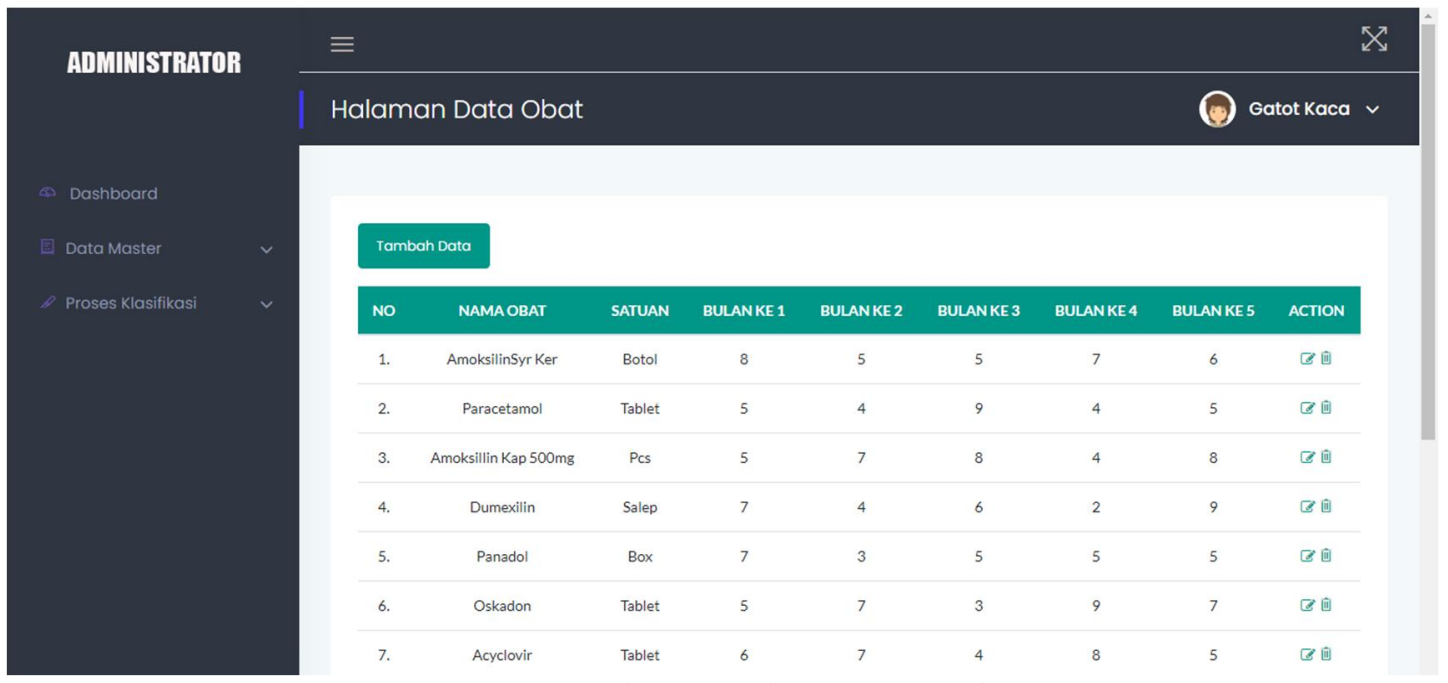

Gambar 4. Halaman Data Obat

Gambar 4 merupakan tampilan menu data obat. Pada halaman ini digunakan untuk mengelola data obat. Mulai dari menambah data, mengubah dan menghapus data obat.

d. Halaman Proses Klasifikasi
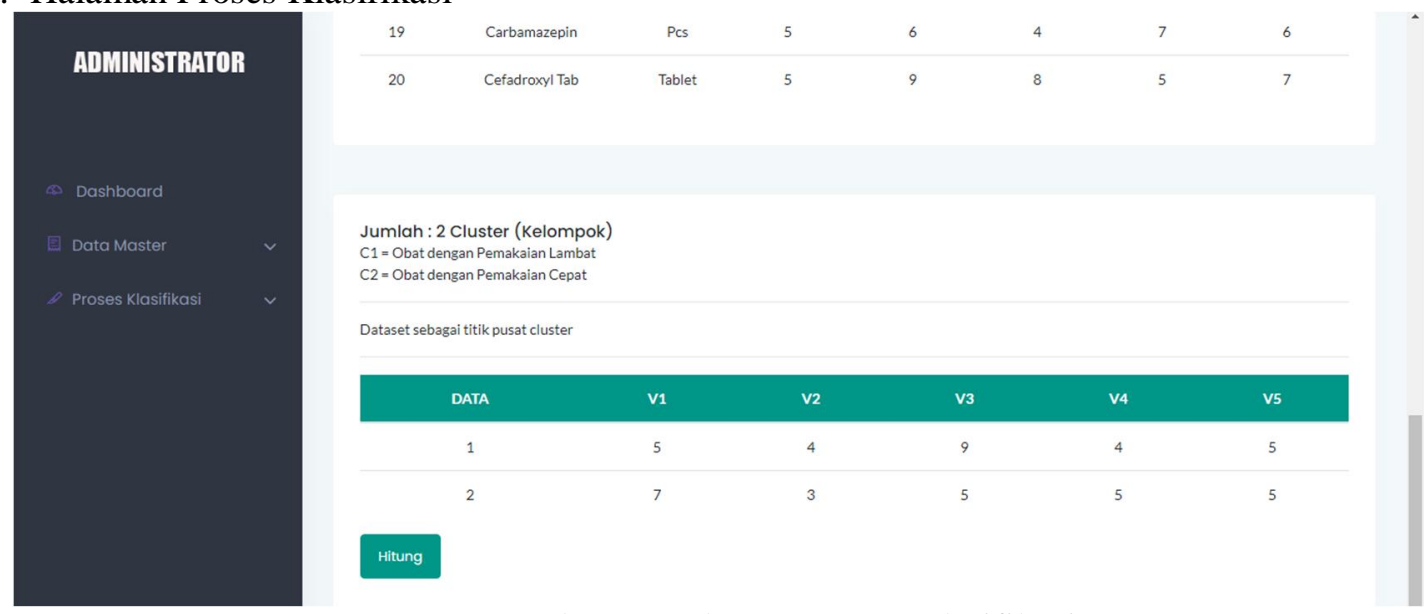

Gambar 5. Halaman Proses Klarifikasi

Gambar 5 merupakan tampilan proses klasifikasi. Pada halaman ini berisikan data obat dan penentuan pusat cluster pertama yang diambil secara random sebanyak 2 record. Dua record ini yang nantinya digunakan sebagai kaitan dari hitungan metode K-means Clustering.

e. Halaman Hasil Perhitungan Iterasi 


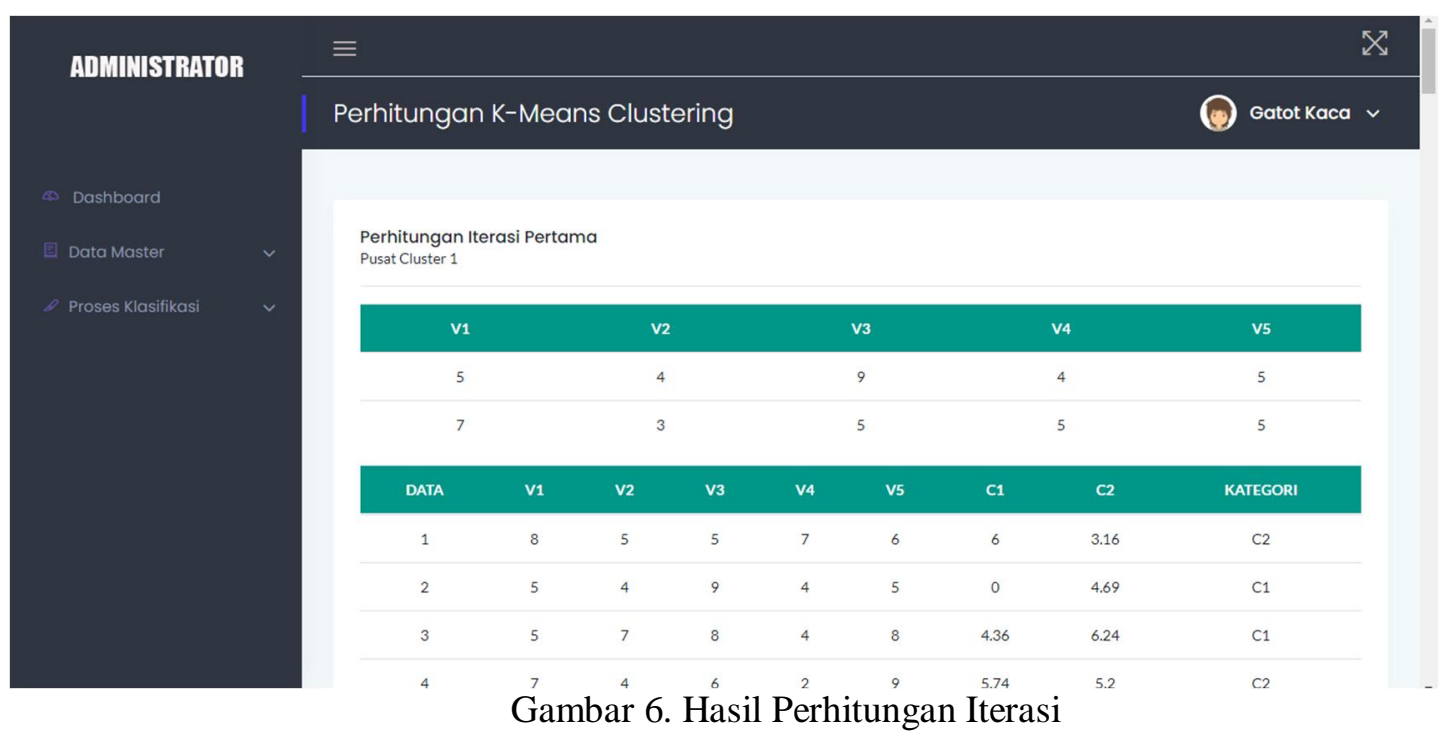

Gambar 6 merupakan tampilan halaman hasil perhitungan iterasi data obat sesuai dengan metode. Hasil perhitungan sampai 3 iterasi.

\section{KESIMPULAN}

Dalam proses algoritma K-Means, centroid pertama ditentukan secara acak. Oleh karena itu, setiap data memiliki peluang yang sama untuk terpilih sebagai centroid pertama. Algoritma K-Means suboptimal terdiri dari penentuan centroid awal. Perubahan centroid awal mempengaruhi nilai keseluruhan untuk hasil clustering yang optimal dan mengubah validasi. Hasil eksperimen dengan menggunakan dua kategori data menunjukkan bahwa jumlah data berpengaruh terhadap hasil optimal cluster.

Pada hasil pengujian dengan 20 data, cluster optimal menyumbangkan 6 data untuk cluster $\mathrm{C} 1$ (obat yang pemakaiaan lambat) dan 1 data untuk cluster $\mathrm{C} 2$ (obat yang pemakaian cepat). Hal ini menunjukkan bahwa data mendekati pusat cluster pembayaran (Pusat). Hasil Clustering yang optimal ditampilkan secara grafis sebagai titik penyesuaian untuk setiap cluster yang mudah dibaca dan dipahami.

\section{SARAN}

Pada penelitian ini mengembangkan aplikasi yang memfasilitasi integrasi data persediaan obat dan transaksi penjualan obat. Diharapkan pada penelitian lanjutan dapat mengembangkan penelitian baru untuk meningkatkan jumlah dan menggabungkannya dengan cara yang berbeda.

\section{DAFTAR PUSTAKA}

[1] Rusdiana 2016, 'Mengukur Kinerja Metode K-Means Dengan Pembanding Dalam Meningkatkan Kualitas Citra X-Ray', 7(3). 
[2] Windarto, A. P. 2017, 'Penerapan Datamining pada Ekspor Buah-buahan Menurut Negara Tujuan Menggunakan K-Means Clustering Method', Techno.Com, 16(4), pp. 348-357. doi: 10.33633/tc.v16i4.1447.

[3] Listiani, L., Agustin, Y. H. and Ramdhani, M. Z. 2017, 'Implementasi Algoritma KMeans Cluster Untuk Rekomendasi Pekerjaan Berdasarkan Pengelompokkan Data Penduduk', pp. 761-769.

[4] Alkhairi, P. and Windarto, A. P. 2019, 'Penerapan K-Means Cluster pada Daerah Potensi Pertanian Karet Produktif di Sumatera Utara', Seminar Nasional Teknologi Komputer \& Sains (SAINTEKS), pp. 762-767.

[5] Aranda, J. and Natasya, W. A. G. 2016, 'Penerapan Metode K-Means Cluster Analysis pada Sistem Pendukung Keputusan Pemilihan Konsentrasi Untuk Mahasiswa International Class Stmik Amikom Yogyakarta', Semnasteknomedia Online, 4(1), pp. 42-1. Available at: https://ojs.amikom.ac.id/index.php/ semnasteknomedia/article/view/1293.

[6] Ghofar, M. A. and Kurniawan, Y. I. 2018, 'Aplikasi Pengelompokan Pelanggan pada Ums Store Menggunakan Algoritma Kmeans, Program Studi Informatika, Fakultas Komunikasi dan Informatika', 4(1).

[7] Bastian, A. et al. 2018, 'Penerapan Algoritma', (1), pp. 26-32.

[8] Asrul Sani 2018," Penerapan Metode K-Means Clustering pada Perusahaan". Jurnal Sistem dan Informatika, 3, 47-60

[9] Saxena, A. et al. 2017, 'A Review of Clustering Techniques and Developments', Neurocomputing. Elsevier, 267, pp. 664-681.

[10] Kumar, K. M. and Reddy, A. R. M. 2017, 'An Efficient K-Means Clustering Filtering Algorithm Using Density Based Initial Cluster Centers', Information Sciences. Elsevier, 418, pp. 286-301.

[11] Saputra, Agus. "Webtrik: PHP, HTML5, dan CSS3” Jakarta, Februari 2018.

[12] Mardiani, Eri, Nur Rahmansyah, Hendra Kurniawan, Dana Indra Sensuse, Jayanta. 2016, Kumpulan Latihan SQL, Elex Media Komputindo, Jakarta. 